\title{
Symptomatic Outcomes of FESS
}

\author{
Mohammed Humaam Ansari*, Atishkumar Balajirao Gujrathi and Vijayalaxmi Ambulgekar \\ Department of Otorhinolaryngology, Dr. Shankarrao Chavan Government Medical College, India
}

Submission: November 16, 2017; Published: December 06, 2017

*Corresponding author: Mohammed Humaam Ansari, Postgraduate Resident, Department of Otorhinolaryngology, Dr. Shankarrao Chavan Government Medical College, Nanded, Maharashtra, India, Email: humaam91@gmail.com

\begin{abstract}
The term 'sinusitis' refers to a group of disorders characterized by inflammation of the mucosa of theparanasal sinuses. Because the inflammation nearly always also involves the nose, it is now generally accepted that 'rhinosinusitis' is the preferred term to describe this inflammation of the nose and paranasal sinuses. Presently, functional endoscopic sinus surgery (FESS) is the standard treatment of chronic rhinosinusitis (CRS) and in sinonasal polyposis. The endoscopic procedure is based on the principles introduced by Messerklinger, which prioritize both the function and the permeability of pre-ethmoidal spaces. In 1985, Kennedy described this technique and popularized the term "Functional Endoscopic Sinus Surgery - FESS".
\end{abstract}

Keywords: FESS; Chronic; Rhinosinusitis; Polyp

Abbreviation: FESS: Functional endoscopic sinus surgery

\section{Introduction}

Endoscopy of nose was first performed by Hirschmann [1] in 1903 using a modified Nitzecystoscope which he used in the nasal cavity and in the maxillary sinus via a tooth socket. In 1922, Speilberg [2] was the first to introduce an endoscope into the maxillary sinus via the inferior meatus, but it was in 1925 that Maltz commissioned Wolf to make a dedicated endoscope. These endoscopes using a series of small lenses continued in use until Hopkins, Professor of Optics at Reading, invented a far superior system in the 1950s, based on solid glass rods, which is now universally in use. Presently, functional endoscopic sinus surgery is the standard treatment of chronic rhinosinusitis (CRS) and in sinonasal polyposis. The endoscopic procedure is based on the principles introduced by Messerklinger, which prioritize both the function and the permeability of pre-ethmoidal spaces. In 1985, Kennedy described this technique and popularized the term "Functional Endoscopic Sinus Surgery - FESS".

\section{Methodology}

This study includes 52 patients who underwent functional endoscopic sinus surgery and consented for participation in the study. Out of 52 patients, 32 patients were diagnosed with sinonasal polyposis and 20 patients were diagnosed with chronic rhinosinusitis (CRS). We excluded recurrences and reoperation cases. The diagnosis of both pathologies was clinical as well as radiological. Medical treatment was attempted for CRS. All patients of CRS were given preoperative medical management with antibiotics and topical steroids for atleast 12 weeks.

All the endoscopic procedures were carried out under general anesthesia. The surgical technique described by Messerklinger and Stammberger was used. All the patients included in the study signed a valid written informed consent explaining the needs and goals of the study. All the patients of nasal polyposis were given preoperative corticosteroids and antibiotics intravenously atleast for 3 days. Injection 2 percent lignocaine (with 1:80,000) adrenaline was used for local infiltration. Post-operatively nasal packing of all the patients with Merocel pack was done which was removed after 36 hours. Average hospital stay was 5 days, with post-operative follow up at 7, 15, 30 days, and at 6 months. Antibiotics and steroids were continued post- operatively and the patients were given nasal douching vigorously with $0.9 \%$ saline solution in their noses. Topical steroids was started 5 days after the procedure, and continued if necessary. Nasal cleaning and crust removal were carried out in the post op follow up.

All these patients answered questionnaires about their symptoms before and after surgery. All the questions were in simple language for better understanding of the patients. Each answer was scored from 0 to 5 according to Likert's scale. In order to analyze the data, we considered good surgery outcome when the score difference between pre and postoperative 
symptoms for each symptom resulted in a positive value equal or above 2 . If the difference resulted in a negative value, equal or above 2, the procedure was considered a failure. In cases which Table 1: Questionnaires.

\begin{tabular}{|c|l|l|l|l|l|}
\hline \multirow{2}{*}{ Symptom } & \multicolumn{2}{|c|}{ Severity of Symptom } \\
\hline & Does not affect (1) & Mild (2) & Moderate (3) & Severe (4) & Incapacitates (5) \\
\hline Nasal obstruction & & & & & \\
\hline Nasal discharge & & & & & \\
\hline Headache & & & & & \\
\hline Loss of olfaction & & & & & \\
\hline Post nasal drip & & & & & \\
\hline Cough & & & & \\
\hline Asthma & & & & \\
\hline Sneezing & & & & \\
\hline
\end{tabular}

\section{Results}

Of all the patients who answered the questionnaire, 28 were male and 24 were female, belonging to age group 07-58 years. They were then separated in two groups, the ones of chronic rhinosinusitis (CRS) alone were 20 in total and those with chronic rhinosinusitis (CRS) and polyp were 32. As for symptomatic health improvement after the procedure, both groups reported excellent outcome.

Table 2: Prevalence of symptoms in patients $(n=52)$.

\begin{tabular}{|c|c|c|}
\hline \multirow{2}{*}{ Symptom } & $\begin{array}{c}\text { Chronic } \\
\text { Rhinosinusitis } \\
\text { (CRS) (n=20) }\end{array}$ & $\begin{array}{c}\text { CRS with Polyp } \\
\text { (n=32) }\end{array}$ \\
\hline Nasal obstruction & $20(100 \%)$ & $32(100 \%)$ \\
\hline Nasal discharge & $17(85 \%)$ & $32(100 \%)$ \\
\hline Headache & $20(100 \%)$ & $27(84.37 \%)$ \\
\hline Anosmia/Hyposmia & $11(55 \%)$ & $22(68.75 \%)$ \\
\hline Post nasal drip & $10(50 \%)$ & $26(81.25 \%)$ \\
\hline Cough & $02(10 \%)$ & $03(9.37 \%)$ \\
\hline Asthma & $01(5 \%)$ & $04(12.5 \%)$ \\
\hline Sneezing & $05(25 \%)$ & $11(34.37 \%)$ \\
\hline Halitosis & $01(5 \%)$ & $02(6.25 \%)$ \\
\hline
\end{tabular}

Table 2 lists the prevalence of symptoms reported by patients with CRS and CRS with polyp. Table 2 depicts the results obtained through FESS. (Table 3) the score difference between pre and post op were between +1 or -1 , we concluded that the procedure did not influence a certain symptom (Table 1).

Table 3: Improvement in symptoms with FESS $(n=52)$.

\begin{tabular}{|c|c|c|c|c|}
\hline & Improved & No change & Worsen & $\begin{array}{c}\text { Symptom } \\
\text { Absent }\end{array}$ \\
\hline $\begin{array}{c}\text { Nasal } \\
\text { obstruction }\end{array}$ & $\begin{array}{c}47 \\
(90.38 \%)\end{array}$ & $05(9.61 \%)$ & 0 & 0 \\
\hline $\begin{array}{c}\text { Nasal } \\
\text { discharge }\end{array}$ & $26(50 \%)$ & $\begin{array}{c}20 \\
(38.46 \%)\end{array}$ & $03(5.76 \%)$ & $03(5.76 \%)$ \\
\hline Headache & $\begin{array}{c}35 \\
(67.30 \%) \\
\end{array}$ & $\begin{array}{c}12 \\
(23.07 \%)\end{array}$ & 0 & 05 (9.61\%) \\
\hline $\begin{array}{l}\text { Anosmia/ } \\
\text { Hyposmia }\end{array}$ & $\begin{array}{c}19 \\
(36.53 \%)\end{array}$ & $\begin{array}{c}14 \\
(26.92 \%)\end{array}$ & 0 & $\begin{array}{c}19 \\
(36.53 \%)\end{array}$ \\
\hline $\begin{array}{c}\text { Post nasal } \\
\text { drip }\end{array}$ & $\begin{array}{c}25 \\
(48.07 \%)\end{array}$ & $\begin{array}{c}11 \\
(21.15 \%)\end{array}$ & $02(3.84 \%)$ & $\begin{array}{c}16 \\
(30.76 \%)\end{array}$ \\
\hline Cough & $04(7.69 \%)$ & 01 (1.92\%) & 0 & $\begin{array}{c}47 \\
(90.38 \%)) \\
\end{array}$ \\
\hline Asthma & $01(1.92 \%)$ & $04(7.69 \%)$ & 0 & $\begin{array}{c}47 \\
(90.38 \%)\end{array}$ \\
\hline Sneezing & $05(9.61 \%)$ & $\begin{array}{c}10 \\
(19.23 \%)\end{array}$ & $01(1.92 \%)$ & $\begin{array}{c}36 \\
(69.23 \%)\end{array}$ \\
\hline Halitosis & $02(3.84 \%)$ & $01(1.92 \%)$ & 0 & $\begin{array}{c}49 \\
(94.23 \%)\end{array}$ \\
\hline
\end{tabular}

\section{Discussion}

The term 'sinusitis' refers to a group of disorders characterized by inflammation of the mucosa of theparanasal sinuses. Because the inflammation nearly always also involves the nose, it is now generally accepted that 'rhinosinusitis' is the preferred term to describe this inflammation of the nose and paranasal sinuses. A widely accepted set of classifications or definitions was developed by the Rhinosinusitis Task Force of the American Academy of Otolaryngology-Head and Neck 
Surgery [3] and reported by Lanza \& Kennedy [4]. These criteria are based in large part on temporal time frames. The distinctions between acute rhinosinusitis (ARS), recurrent acute rhinosinusitis (RARS), subacute rhinosinusitis (SRS), chronic rhinosinusitis (CRS) and acute exacerbation of chronic rhinosinusitis (AECRS) are based on the temporal differences in the presentation and, in some cases, on the clinical presentation. There are also differences in the histopathology and the bacteriology of acute and chronic rhinosinusitis [4]. The major symptoms are nasal obstruction, facial pain/pressure, facial congestion/fullness, rhinorrhea and hyposmia and the minor symptoms are headache, dental pain, halitosis, fatigue, dry cough, fever and earache. 2 major symptoms, one major and 2 minors or purulent discharge in the nasal cavity suggest CRS [5]. The mechanisms behind polyp formation are believed to be multifactorial. A variety of environmental and genetic factors play a role in the pathogenesis of inflammatory polyps and the role of proinflammatory cytokines, chemokines, and chemotactic mediators is increasingly being appreciated [6] (Table 4).

Table 4: Classification of Rhinosinusitis [4].

\begin{tabular}{|c|c|}
\hline Classification & Duration \\
\hline Acute Rhinosinusitis (ARS) & 7 days to $<4$ Weeks \\
\hline SubacuteRhinosinusitis (SRS) & $4-12$ Weeks \\
\hline $\begin{array}{c}\text { Recurrent Acute Rhinosinusitis } \\
\text { (RARS) }\end{array}$ & $>4$ Episodes of ARS per year \\
\hline $\begin{array}{c}\text { Chronic Rhinosinusitis (CRS) } \\
\text { Acute Exacerbation Of }\end{array}$ & $\begin{array}{c}\text { Sudden Worsening Of CRS With } \\
\text { Return }\end{array}$ \\
\hline Chronic Rhinosinusitis (AECRS) & To Baseline After \\
\hline
\end{tabular}

Nasal endoscopy and imaging were not used in this study to quantify the clinical management of chronic rhinosinusitis because chronic rhinosinusitis is a symptom-based condition, and symptom-free patients usually does not require additional treatment, even when they present minor alterations in endoscopic examination or mucosal thickening in CT scans of the paranasal sinuses.

Nasal obstruction, rhinorrhea and headache are the CRS symptoms that most impact patient's quality of life. In our study, these were also frequent complaints. Nasal obstruction was present in $100 \%$ of the patients, rhinorrhea in $94.23 \%$ and headaches in $90.38 \%$.

In present study, symptoms that had the most improvement after surgery were nasal obstruction (90.38\% improvement) followed by headache $(67.30 \%$ improvement $)$ and nasal discharge (50\% improvement). Polyp patients had a trend of presenting with greater symptoms relief after surgery.

Damm et al. [7] observed improvements of $84 \%$ in nasal obstruction, $77.8 \%$ in rhinorrhea, $82 \%$ in headache, $78 \%$ in post nasal drip and $73.2 \%$ in hyposmia after sinus surgery.

Dursun et al. [8] observed improvements of $89.18 \%$ in nasal obstruction, $85.71 \%$ in rhinorrhea, $86.73 \%$ in headache, $88.88 \%$ in post nasal drip and77.58 \% in hyposmia after sinus surgery (Table 5).

Table 5: Comparison between different studies.

\begin{tabular}{|c|c|c|c|}
\hline $\begin{array}{c}\text { Post-operative } \\
\text { Improvement } \\
\text { in Symptoms }\end{array}$ & Present Study & $\begin{array}{c}\text { Damm et al. } \\
\text { [7] }\end{array}$ & $\begin{array}{c}\text { Dursun et al. } \\
\text { [8] }\end{array}$ \\
\hline $\begin{array}{c}\text { Nasal } \\
\text { obstruction }\end{array}$ & $90.38 \%$ & $84 \%$ & $89.18 \%$ \\
\hline $\begin{array}{c}\text { Nasal } \\
\text { discharge }\end{array}$ & $50 \%$ & $77.80 \%$ & $85.71 \%$ \\
\hline Headache & $67.30 \%$ & $82 \%$ & $86.73 \%$ \\
\hline $\begin{array}{c}\text { Anosmia/ } \\
\text { Hyposmia }\end{array}$ & $36.53 \%$ & $73.20 \%$ & $77.58 \%$ \\
\hline $\begin{array}{c}\text { Post nasal } \\
\text { drip }\end{array}$ & $48.07 \%$ & $78 \%$ & $88.88 \%$ \\
\hline Cough & $7.69 \%$ & -- & $92.85 \%$ \\
\hline Asthma & $1.92 \%$ & -- & -- \\
\hline Sneezing & $9.61 \%$ & -- & -- \\
\hline Halitosis & $3.84 \%$ & -- & $85.71 \%$ \\
\hline
\end{tabular}

\section{Conclusion}

The objective of this study was to determine if patients undergoing functional endoscopic sinus surgery (FESS) obtain significant symptomatic benefit from surgery. The leading complaints within the symptomatic profile of patients with chronic rhinosinusitis are nasal obstruction, nasal discharge and headache. The restriction of quality of life in patients with chronic rhinosinusitis is mainly caused by these symptoms, which can be improved in excellent fashion by functional endoscopic sinus surgery in the majority of patients, achieving better quality of life in the long term.

\section{References}

1. Hirschmann A (1903) Uber Endoskopie der Nae und derenNebenhohlen. ArchivfürLaryngologie und Rhinologie 14: 195-200.

2. Speilberg W (1922) Antroscopy of the maxillary sinus. Laryngoscope 32: 441.

3. (1997) Report of the Rhinosinusitis Task Force Committee Meeting. Otolaryngol Head Neck Surg (3 Pt 2): S1-68.

4. Lanza DC, Kennedy DW (1997) Adult rhinosinusitis defined. Otolaryngol Head Neck Surg 117(3 Pt 2): S1-7.

5. Michael G, George GB, Martin J, Ray C, John H, et al. (2008) ScottBrown's Otorhinolaryngology, Head and Neck Surgery. In: Michael G, George GB, Martin J, Ray C, John H, et al. (eds.), ( $7^{\text {th }}$ Edn), Edward Arnold (Publishers) Ltd, London, Volume2 , p.1440.

6. James BS, Ballenger's JJ (2002) Ballenger's Manual of Otorhinolaryngology Head and Neck Surgery. In: James BS, Ballenger's JJ (eds.), BC Decker Publishers, London, p. 278.

7. Damm M, Quante G, Jungehuelsing M, Stennert E (2002) Impact of functional endoscopic sinus surgery on symptoms and quality of life in chronic rhinosinusitis. Laryngoscope 112(2): 310-315.

8. Dursun E, Korkmaz H, Eryilmaz A, Bayiz U, Sertkaya D, et al. (2003) Clinical predictors of long-term success after endoscopic sinus surgery. Otolaryngol Head Neck Surg 129(5): 526-531. 


\section{Your next submission with Juniper Publishers will reach you the below assets}

- Quality Editorial service

- Swift Peer Review

- Reprints availability

- E-prints Service

- Manuscript Podcast for convenient understanding

- Global attainment for your research

- Manuscript accessibility in different formats ( Pdf, E-pub, Full Text, Audio)

- Unceasing customer service

Track the below URL for one-step submission https://juniperpublishers.com/online-submission.php 